\title{
New records of isopod species of the Antarctic Specially Managed Area No. 1, Admiralty Bay, South Shetland Islands
}

\author{
Karol ZEMKO, Krzysztof PABIS*, Jacek SICIŃSKI and Magdalena BŁAŻEWICZ \\ Laboratory of Polar Biology and Oceanobiology, University of Łódź, \\ Banacha 12/16, 90-237 Łódź, Poland \\ * corresponding author <cataclysta@wp.pl>
}

\begin{abstract}
Admiralty Bay (King George Island) is an Antarctic Specially Managed Area and one the most thoroughly studied small-scale marine basins in the Southern Ocean. Our study provides new data on the isopod fauna in this glacially affected fjord. Twelve species of isopods were recorded in this basin for the first time. Six of them were found for the first time in the region of the South Shetland Islands. The highest number of species new for Admiralty Bay were found in the families Munnopsidae (4 species) and Munnidae (3 species).
\end{abstract}

Key words: Antarctic, King George Island, Crustacea, glacial fjords, ASMA, biodiversity.

\section{Introduction}

General knowledge about the biodiversity of the Antarctic benthic fauna has increased in recent years as a result of intensified sampling programs and the creation of large databases like the Register of Antarctic Marine Species (RAMS), a key element of the SCAR Mar-BIN program (De Broyer et al. 2011; Griffiths et al. 2011; Jossart et al. 2015). Results of large international programs like the Census of Antarctic Marine Life (CAML) and the ANtarctic benthic DEEP-sea biodiversity: colonization history and recent community patterns (ANDEEP) has increased our knowledge about the distribution of benthic marine life in the Southern Ocean and resulted in findings of many new taxa, especially in the deep sea (Brandt et al. 2007). The proportion of new taxa in various collections from different Antarctic locations is still very high even in shallower shelf areas (e.g. Pabis et al. 2015). Some regions of the Southern Ocean, including large parts of the West Antarctic, are relatively well-studied in terms of biodiversity (Griffiths 
2010). Nevertheless, there is a need to develop the network of monitoring sites that can be treated as reference points for future studies describing the influence of global changes on marine diversity, especially in the region of the West Antarctic Peninsula (Moon et al. 2015; Sahade et al. 2015). Ongoing, rapid climate warming observed in this part of the world (Walsh 2009) implies the necessity of detailed biodiversity assessments, especially in the protected areas and in basins that can be included in the list of monitoring sites. This approach fits also in the general concept of the All Taxa Biodiversity Inventory (ATBI) sites that was originally proposed over 20 years ago (Yoon 1993) but it is still developed in many marine and terrestrial sites, including polar fjords (Kędra et al. 2010).

Admiralty Bay is one of the most comprehensively studied small scale areas in the Southern Ocean. Over 1300 benthic species (e.g., 172 species of amphipods, 162 of polychaetes, 135 species of foraminiferans, 80 species of echinoderms, 48 species of gastropods and 39 species of bivalves) were recorded in this bay over 35+ years of Polish, Brazilian and German research (Sicinski et al. 2011). In 1996 it was designated by the Scientific Committee on Antarctic Research as an Antarctic Specially Managed Area (ASMA No. 1) and as an "important area which might warrant future consideration as legacy site requiring special protection" (Siciński et al. 2011). There are about 100 papers focusing on various aspects of marine life in this basin. Some of them (Pabis et al.2011; Siciński et al. 2012) were recently included in the compilation of circumpolar information on Antarctic benthic communities that "provides unique georeferenced biological basic information" (Gutt et al. 2013) for the future studies prepared under the umbrella of various international programs like Antarctic Thresholds - Ecosystem Resilience and Adaptation as well as planning of Marine Protected Areas. As pointed out in one of the CAML contributions this semi-closed glacially affected ecosystem is a perfect model system for studies of influence of warming on marine benthic fauna (Siciński et al. 2011).

Isopods are among the most speciose groups of benthic macrofauna of the Southern Ocean (De Broyer et al. 2011) and third most speciose group of benthic macrofauna of Admiralty Bay (Arnaud et al. 1986; Presler 1986; Teodorczyk and Wägele 1994; Zemko and Brix 2012; Siciński et al. 2012; Zemko and Kaiser 2012; Zemko et al. 2015, 2017). However, recent studies of the soft-bottom isopod communities demonstrated that despite the very large sampling effort the species accumulation curves are still steep and a comprehensive evaluation of the isopod species richness in this basin is still far from being complete (Zemko et al. 2017). Our study provides new data on species richness of the isopod fauna of Admiralty Bay, which will enhance future biodiversity assessments of this basin. 


\section{Material and methods}

Study area. - Admiralty Bay is a medium-size glacial basin on the King George Island (South Shetlands). It covers an area of about $120 \mathrm{~km}^{2}$. It consists of a central basin and three inner fjords: Ezcurra Inlet, Martel Inlet and MacKellar Inlet. Large part of the Admiralty Bay coastline is covered with glaciers and icefalls (Braun and Grossmann 2002). The bay is strongly affected by various glacial processes (Pęcherzewski 1980; Lipski 1987; Campos 2013). Admiralty Bay is influenced by Bellingshausen Sea and Weddell Sea waters (Tokarczyk 1987). Bottom deposits are poorly sorted. The sediments can be described as sand (in the shallow sublittoral zone) and mud (silty clay sand and sandy clay silt) in deeper parts of the bay (Siciński 2004; Campos 2013). The phytal zone covers about $30 \%$ of the Admiralty Bay bottom (Zieliński 1990). Detailed description of hydrology and other environmental characteristics of this basin were recently summarized by Siciński et al. (2011).

\section{Sampling}

We gathered new records of isopod species from 21 random van Veen grab $\left[0.1 \mathrm{~m}^{2}\right]$ samples collected in the summer season of the 1978, 1979/1980 (13 samples) and 2007 (8 samples). Larger series of 32 bottom trawls collected in the summer season of 1977/78 (5 samples) and summer season of the 1980/1981 (27 samples) were also used in the analysis. Material was collected along a full depth range of Admiralty Bay (13-165 m for van Veen grab samples, 15-500 m for the trawling samples) and in different parts of Admiralty Bay, mainly in Ezcurra Inlet and central basin. Samples were sieved on a $0.5 \mathrm{~mm}$ mesh sieve and preserved in $4 \%$ formalin solution. After sorting material was fixed in alcohol.

\section{Results and discussion}

Twelve species of Isopoda new to Admiralty Bay were recorded in the studied material (Table 1). Those species represented six families. The highest number of new species were found in the families Munnopsidae (4 species) and Munnidae ( 3 species). Both of those families are also very common and speciose in the whole Southern Ocean. There are 95 species of Munnopsidae and 34 species of Munnidae known from this part of the World Ocean (Kaiser 2014). All the families except Stenetriidae were already found in previous research. Generally, the species richness of isopods in Admiralty Bay is high, especially when taking into account the small size of this basin. Currently 441 species of Isopoda are recorded in the whole Southern Ocean (De Broyer et al. 2011), 
while the number of species found in the Admiralty Bay, together with our present results equals 99 (Arnaud et al. 1986; Presler 1986; Teodorczyk and Wägele 1994; Zemko and Brix 2011; Zemko and Kaiser 2012; Siciński et al. 2012; Zemko et al. 2015). This further highlights the fact that this bay is an important biodiversity hot spot for the benthic fauna. It was already suggested that the high diversity of habitats (including different types of soft and hard bottom, macroalgae forests) and dynamic set of environmental properties can be a reason of high diversity of the Admiralty Bay macrofauna in many taxonomic groups (Siciński et al. 2011). High diversity of habitats can be vitally important in the case of isopods, because their distribution in the Admiralty Bay is very patchy and most of the species were rare (Zemko et al. 2017). Therefore, there is a need for further studies based on large sampling effort, and exploration of different types of habitats. Moreover, our study showed that the use of different sampling gears like bottom trawls might also contribute to finding of some new taxa. Differences in species composition were observed for example in the case of polychaetes studied with the use of a van Veen grab and bottom trawl in the Admiralty Bay (Siciński 2004; Pabis and Sicinski 2010). Until now most of the data on the isopod fauna in Admiralty Bay based on van Veen grab samples collected at point scale or samples collected from kelp holdfasts (Zemko et al. 2015). On the other hand this basin is also undoubtedly very well studied, and this fact results in a more comprehensive list of taxa.

The majority of the species new to Admiralty Bay were recorded in the middle sublittoral zone. Only Cryosignum incisum (Richardson 1908) was found in the shallowest sublittoral and it seems that this species is generally associated only with the shallower sublittoral zone (Doti et al. 2005). Most of the species found in our study were singletons, doubletons and tripletons, which supports earlier results from the Admiralty Bay soft bottom (Zemko et al. 2017) and other studies showing low densities of the Antarctic isopods (Richardson and Hedgpeth 1977; Brandt 2001), although it is worth mentioning that van Veen grab is not a perfect tool for isopod sampling. A higher number of individuals was found only for Eurycope crassiramis Golovan, 2008 and Coulmannia australis Hodgson, 1910, however both species were found in two samples only. Despite the fact that the knowledge on isopod species richness in the studied region is relatively comprehensive, six of the species were found for the first time in the South Shetland Islands (Castello 2004 and references therein). Most of those species were already recorded in the West Antarctic. Some of them are also known from East Antarctic and subantarctic islands, mostly from very similar depth ranges (Table 1).

Only in the case of one species recorded in our study we noted important information about its whole range in the Southern Ocean. Coperonus nordenstami Wilson, 1989 has been previously recorded only from South Georgia (Wilson 1989). Our study further provides new data on bathymetric distribution of some 
Table 1

List of isopod species new for the Admiralty Bay. Species recorded in the South Shetland Islands for the first time are marked with an asterisk. W - West Antarctic, E - East Antarctic, S - Scotia Arc, G - South Georgia.

\begin{tabular}{|c|c|c|c|c|c|c|}
\hline & $\begin{array}{l}\text { Number } \\
\text { of indi- } \\
\text { viduals }\end{array}$ & $\begin{array}{l}\text { Sample } \\
\text { details } \\
\text { (No. of } \\
\text { samples in } \\
\text { brackets) }\end{array}$ & $\begin{array}{l}\text { Depth range } \\
\text { [m] in the } \\
\text { Antarctic } \\
\text { (literature } \\
\text { data) }\end{array}$ & $\begin{array}{l}\text { Depth } \\
\text { range } \\
\text { [m] in } \\
\text { present } \\
\text { study }\end{array}$ & References & $\begin{array}{l}\text { Distri- } \\
\text { bution } \\
\text { in the } \\
\text { SO }\end{array}$ \\
\hline \multicolumn{7}{|c|}{ Acanthaspidiidae } \\
\hline $\begin{array}{l}\text { Ianthopsis } \\
\text { ruseri } \\
\text { Vanhöffen, } \\
1914\end{array}$ & 2 & $\begin{array}{c}\text { bottom } \\
\text { trawl (2), } \\
23 \text { I, } \\
24 \text { III } \\
1981\end{array}$ & 385 & $70-240$ & $\begin{array}{c}\text { Castello (2004), } \\
\text { Brandt (1991), } \\
\text { Choudhury and Brandt } \\
\text { (2009) }\end{array}$ & $\mathrm{W} / \mathrm{E}$ \\
\hline \multicolumn{7}{|c|}{ Desmosomatidae } \\
\hline $\begin{array}{l}\text { Whoia } \\
\text { sp. nov.* }\end{array}$ & 1 & $\begin{array}{l}\text { van Veen } \\
\text { grab (1), } \\
28 \text { III } \\
2007\end{array}$ & - & 112 & $\begin{array}{l}\text { Brix (2006), Kaiser } \\
\quad \text { et al. (2007) }\end{array}$ & $\mathrm{W}$ \\
\hline \multicolumn{7}{|c|}{ Munnidae } \\
\hline $\begin{array}{l}\text { Munna } \\
\text { maculata } \\
\text { Beddard, } \\
1886\end{array}$ & 3 & $\begin{array}{l}\text { van Veen } \\
\text { grab, (3), } \\
27 \text { III, } \\
28 \text { III, } \\
28 \text { III } \\
2007\end{array}$ & $22-141$ & $109-145$ & $\begin{array}{c}\text { Castello (2004), } \\
\text { Choudhury and Brandt } \\
\text { (2009) Teodorczyk } \\
\text { and Wägele (1994), } \\
\text { Amar and Roman } \\
\text { (1974) }\end{array}$ & $\mathrm{W} / \mathrm{E} / \mathrm{S}$ \\
\hline $\begin{array}{l}\text { Munna } \\
\text { psychrophila } \\
\text { Vanhöffen, } \\
1914^{*}\end{array}$ & 2 & $\begin{array}{l}\text { van Veen } \\
\text { grab, (2), } \\
27 \text { III, } \\
28 \text { III } \\
2007\end{array}$ & $10-1153$ & $112-116$ & $\begin{array}{c}\text { Schotte } 2008 b, \\
\text { Teodorczyk } \\
\text { and Wagele } 1994\end{array}$ & $\mathrm{~W} / \mathrm{E}$ \\
\hline \begin{tabular}{|l|} 
Munna \\
studeri \\
Hilgendorf, \\
$1893^{*}$
\end{tabular} & 2 & $\begin{array}{l}\text { van Veen } \\
\text { grab, (2), } \\
27 \text { III } \\
2007\end{array}$ & $0-210$ & $108-110$ & $\begin{array}{c}\text { Choudhury and Brandt } \\
\text { (2009), Teodorczyk } \\
\text { and Wägele (1994) }\end{array}$ & $\mathrm{W} / \mathrm{E} / \mathrm{S}$ \\
\hline \multicolumn{7}{|c|}{ Munnopsidae } \\
\hline \begin{tabular}{|l} 
Eurycope \\
crassiramis \\
Golovan, \\
$2008^{*}$ \\
\end{tabular} & 8 & $\begin{array}{l}\text { van Veen } \\
\text { grab (2), } \\
27 \text { III } \\
2007\end{array}$ & 1582 & $108-112$ & Golovan (2008) & $\mathrm{W}$ \\
\hline $\begin{array}{l}\text { Coperonus } \\
\text { gracilis } \\
\text { Brandt, } 1992\end{array}$ & 2 & $\begin{array}{l}\text { van Veen } \\
\text { grab, (2), } \\
27 \text { III, } \\
28 \text { III } \\
2007\end{array}$ & $45-420$ & $108-145$ & $\begin{array}{l}\text { Castello (2004), } \\
\text { Brandt (1992), Wilson } \\
\text { and Shotte (2009), } \\
\text { Doti et al. }(2005)\end{array}$ & W \\
\hline $\begin{array}{l}\text { Coperonus } \\
\text { nordenstami } \\
\text { Wilson, } \\
1989^{*}\end{array}$ & 2 & $\begin{array}{l}\text { van Veen } \\
\text { grab (1), } \\
28 \text { III } \\
2007\end{array}$ & $252-310$ & 116 & Wilson 1989 & G \\
\hline
\end{tabular}


Table 1 continued

\begin{tabular}{|c|c|c|c|c|c|c|}
\hline & $\begin{array}{l}\text { Number } \\
\text { of indi- } \\
\text { viduals }\end{array}$ & $\begin{array}{l}\text { Sample } \\
\text { details } \\
\text { (No. of } \\
\text { samples in } \\
\text { brackets) }\end{array}$ & $\begin{array}{l}\text { Depth range } \\
\text { [m] in the } \\
\text { Antarctic } \\
\text { (literature } \\
\text { data) }\end{array}$ & $\begin{array}{l}\text { Depth } \\
\text { range } \\
\text { [m] in } \\
\text { present } \\
\text { study }\end{array}$ & References & $\begin{array}{l}\text { Distri- } \\
\text { bution } \\
\text { in the } \\
\text { SO }\end{array}$ \\
\hline $\begin{array}{l}\text { Lionectes } \\
\text { humicepha- } \\
\text { lotus Wilson, } \\
1989\end{array}$ & 1 & $\begin{array}{l}\text { van Veen } \\
\text { grab (1), } \\
28 \text { III } \\
2007\end{array}$ & $6-659$ & 112 & $\begin{array}{l}\text { Castello (2004), } \\
\text { Wilson (1989) }\end{array}$ & W \\
\hline \multicolumn{7}{|c|}{ Paramunnidae } \\
\hline $\begin{array}{l}\text { Cryosignum } \\
\text { incisum } \\
\text { (Richardson, } \\
1908)^{*}\end{array}$ & 1 & $\begin{array}{l}\text { van Veen } \\
\text { grab (1), } \\
7 \text { III } 1980\end{array}$ & $0-15$ & 17 & $\begin{array}{c}\text { Doti et al. (2005), } \\
\text { Just and Wilson } \\
(2007)\end{array}$ & W \\
\hline $\begin{array}{l}\text { Coulmannia } \\
\text { australis } \\
\text { Hodgson, } \\
1910\end{array}$ & 5 & $\begin{array}{c}\text { bottom } \\
\text { trawl, (2), } \\
17 \text { III } \\
1981\end{array}$ & $183-400$ & $290-430$ & $\begin{array}{c}\text { Castello (2004), } \\
\text { Schotte (2008a), } \\
\text { Choudhury and Brandt } \\
\text { (2009) }\end{array}$ & $\mathrm{W} / \mathrm{E}$ \\
\hline \multicolumn{7}{|c|}{ Stenetriidae } \\
\hline $\begin{array}{l}\text { Tenupedun- } \\
\text { culus acutum } \\
\text { (Vanhöffen, } \\
\text { 1914) }\end{array}$ & 3 & $\begin{array}{c}\text { bottom } \\
\text { trawl (1), } \\
24 \text { III } \\
1981\end{array}$ & $150-3397$ & 240 & $\begin{array}{c}\text { Castello (2004), Serov } \\
\text { and Wilson (1995), } \\
\text { Nordenstam (1933), } \\
\text { Zimmerman and } \\
\text { Brandt (1992) }\end{array}$ & $\mathrm{W} / \mathrm{E}$ \\
\hline
\end{tabular}

other species (Table 1), although in most cases our data only slightly increased the current knowledge. Eurycope crassiramis has been previously found only in the deep sea $(1582 \mathrm{~m})$. It was recorded for the first time since its original description and it has been previously known only from the locus typicus in the northern part of the Weddell Sea, in a relatively short distance from the South Shetlands (Golovan 2008). Generally, there are isopod species in the Southern Ocean that have wide or even circumpolar distributions or can be found along large bathymetric ranges (Kaiser 2014). Some families, like Munnopsidae, have good swimming abilities (Brix and Svavarsson 2010; Brandt et al. 2011). Many species may float on thalli and holdfasts of large macroalage drfiting with the Antarctic Circumpolar Current (Edgar 1987).

We also discovered a first record of the genus Whoia on the shelf of the South Shetland Island. This desmosomatid isopod genus includes only four described species. W. angusta (G.O. Sars, 1899) is known from Skagerrak Strait, W. dumbshafensis Svavarsson, 1988 was described from the North Sea. Two other species, W. variabilis Hessler, 1970 and W. victoriensis Brix, 2006, are known from the North Atlantic and the Australian waters respectively (Brix 2006). In the Southern Ocean it was recorded only in the deep sea (Kaiser et al. 2007) but it was still not formally described. In the material from the Admiralty Bay 
it was represented by only a single individual and that is why we have not decided to describe it as a new species.

Admiralty Bay as an ASMA site needs special attention in biodiversity studies. Isopods are one of the most speciose groups of invertebrates of this basin, just after Amphipoda and Polychaeta (Siciński et al. 2011). As good indicators of environmental changes that are sensitive to ongoing climate warming in the region of the Antarctic Peninsula (Ingels et al. 2012) this invertebrate group is also important for the future studies describing changes in biodiversity, especially in comprehensively studied reference sites located along the Antarctic Peninsula. High diversity of the Admiralty Bay bottom fauna and its geographic position makes this basin not only a good monitoring point but also a scientific legacy site. Several species of macrofauna, including six isopod species, have type localities in this basin which further confirms its scientific and historic legacy (Teodorczyk and Wägele 1994; Siciński et al. 2011; Zemko and Brix 2011; Zemko and Kaiser 2012). A high level of rarity of some isopod species found in the Admiralty Bay shows the importance of a comprehensive species richness assessment of this basin. Over 250 benthic samples were collected with use of various sampling gears like: bottom trawls, epibenthic sledge, box corers and van Veen grabs during many Polish, Brazilian and German sampling campaigns. Nevertheless, there are still some species like Whoia sp., Lionectes humicephalotus or Cryosignum incisum that are known in this basin from only one single specimen (Table 1). Climate changes might influence the small populations of some of those species in the Admiralty Bay, therefore it is important to monitor and document new records of taxa in this basin as a basis for future research. Further studies should be based on material collected with use of different sampling methods.

Acknowledgments. - The study was supported by a grant of the Polish Ministry of Science and Higher Education No 51/N-IPY/2007/0 as well as the Census of Antarctic Marine Life project. Karol Zemko and Krzysztof Pabis were also supported by University of Łodz internal funds. We are very grateful to three reviewers for all important suggestions. Thanks are also due to David Drumm who kindly corrected language through the manuscript.

\section{References}

Amar R. and Roman M.L. 1974. Invertébrés marins des XIIème et XVème Expéditions Antarctiques Françaises en Terre Adélie. 14. Tanaidacés et Isopodes. Tethys 5: 561-600.

ARnAUd P.M., JAŻDŻEWSKI K., PRESLER P. and SicińSKi J. 1986. Preliminary survey of benthic invertebrates collected by Polish Antarctic Expeditions in Admiralty Bay (King George Island, South Shetland Islands, Antarctica). Polish Polar Research 7: 7-24.

BRANDT A. 1991. A revision of the Acanthaspidiidae Menzies, 1962 (Isopoda: Asellota). Zoological Journal of the Linnean Society 102: 203-252. 
BRANDT A. 1992. The genus Coperonus Wilson, 1989 (Crusatcea: Isopoda: Asellota: Munnopsidae). Zoological Journal of the Linnean Society 106: 63-95.

BRANDT A. 2001. Great differences in peracarid crustacean density between the Arctic and Antarctic deep sea. Polar Biology 24: 785-789.

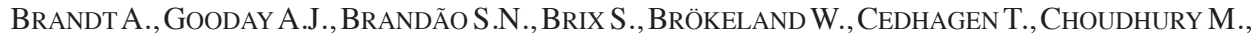
Cornelius N., Danis B., De Mesel I., Diaz R.J., Gillan D.C., Ebbe B., Howe J.A., JanusSEN D., KAISER S., LinSE K., MALYUTinA M., PAWlOWSKi J., RAUPACH M. and VANREUSEL A. 2007. First insights into the biodiversity and biogeography of the Southern Ocean deep sea. Nature 447: 307-311.

Brandt A., Bathmann U., Brix S., Cisewski B., Flores H., Gocke C., Janussen D., KragefSKy S., Kruse S., Leach H., Linse K., Pakhomov E., Peeken I., Riehl T., Sauter E., Sachs O., SchUller M., Schrodl M., Schwabe E., Strass V., VAN FraneKer J.A. and WilmSEN E. 2011. Maud Rise - a snap shot through the water column. Deep-Sea Research II 58: 1962-1982.

Braun M. and Grossmann H. 2002. Glacial changes in the areas of Admiralty Bay and Potter Cove, King George Island, maritime Antarctica. In: L. Beyer and M. Bolter (eds), Geoecology of the Antarctic ice-free coastal landscapes. Springer, Berlin: 75-90.

BRIX S. 2006. A new genus and new species of Desmosomatidae (Crustacea: Isopoda: Asellota) from the deep sea of south-eastern Australia. Memoirs of Museum Victoria 63: 175-205.

BRIX S. and SVAVARSSON J. 2010. Distribution and diversity of desmosomatid and nannoniscid isopods (Crustacea) on the Greenland-Iceland-Faeroe Ridge. Polar Biology 33: 515-530.

Campos L.S., Barboza C.A.M., Bassoi M., Bernardes M., Bromberg S., Corbisier T.N., Fontes R.F., Gheller P.F., HaJdu E., KaWAll H.G., LANGe P.K., LanNa A.M., LAVRADo H.P., Monteiro G.C.S., Montone R.C., Morales T., Moura R.B., NaKayama C.R., Oackes T., Paranhos R., Passos F.D., Petti M.A.V., Pellizari V.H., Rezende C.E., RodRigues M., Rosa L.H., Secchi E., Tenenbaum D. and Yoneshigue-VAlentin Y. 2013. Environmental Processes, Biodiversity and Changes in Admiralty Bay, King George Island, Antarctica. In: G. di Prisco and C. Verde (eds), Adaptation and Evolution in Marine Environments, Vol. 2 Springer, Berlin: 127-156.

CASTELlo J. 2004. Isopods (Crustacea, Isopoda) from the Spanish "Bentart-94/95" expeditions to the South Shetland Islands (sub-Antarctic). Polar Biology 28: 1-14.

Choudhury M. and BrandT A. 2009. Benthic isopods (Crustacea, Malacostraca) from the Ross Sea, Antarctica: species checklist and their zoogeography in the Southern Ocean. Polar Biology 32: 599-610.

De Broyer C., Danis, B., Allcock L., Angel M., Arango C., Artois T., Barnes, D., BartSch I., Bester M., Blachowiak-Samolyk K., BŁaŻewicz M., Bohn J., Brandt A., Brandao S.N., David B., de Salas M., Eleaume M., Emig C., Fautin D., George K.H., Gillan D., Gooday A., Hopcroft R., Jangoux M., Janussen D., Koubbi P., Kouwenberg J., KuKlińsKi P., Ligowski R., LindSAY D., LinSE K., LONGSHAW M., LOPEZ-GONZALEZ P., Martin P., Munilla T., Muhlenhardt-Siegel U., Neuhaus B., Norenburg J., Ozouf-Costaz C., Pakhomov E., Perrin W., Petryashov V., Pena-Cantero A.L., Piatkowski U., Pierrot-Bults A., Rocka A., Saiz-Salinas J., Salvini-Plawen L., Scarabino V., Schiaparelli S., Schrodl M., Schwabe E., Scott F., Sicinski J., Siegel V., Smirnov I., Thatje S., Utevsky A., VANReusel A., Wiencke C., Woehler E., ZdZITOWIECKI K. and Zeidler W. 2011. How many species in the Southern Ocean? Towards a dynamic inventory of the Antarctic marine species. Deep-Sea Research Part II - Topical Studies in Oceanography 58: 5-17.

Doti B.L., Roccatagliata D. and Zelaya D.G. 2005. The shallow-water Asellota (Crustacea: Isopoda) from the Beagle Channel: preliminary taxonomic and zoogeographic results. Scientia Marina 69: 159-166. 
EDGaR G.J. 1987. Dispersal of faunal and floral propagules associated with drifting Macrocystis pyrifera plants. Marine Biology 95: 599-610.

Golovan O.A. 2008. Eurycope crassiramis sp. nov., a new species of Munnopsidae (Crustacea, Isopoda, Asellota) from the Weddell Sea, Southern Ocean. Zootaxa 1866: 540-554.

GRIFFITHS H.J. 2010. Antarctic marine biodiversity - What do we know about the distribution of life in the Southern Ocean? PLOS ONE 5: e11683.

GUTT J., BARNES D., LOCKHART S.J. and VAN DE PUTTE A. 2013. Antarctic macrobenthic communities: a compilation of circumpolar information. Nature Conservation 4: 1-13.

Ingels J., Vanreusel A., Brandt A., Catarino A.I., David B., De Ridder C., Dubois P., Gooday A.J., MARTIN P., PASOTti F. and RoberT H. 2012. Possible effects of global environmental changes on Antarctic benthos: a synthesis across fi ve major taxa. Ecology and Evolution 2: 453-485.

Jossart Q., Moreau C., Agüera A., De Broyer C. and Danis B. 2015. The Register of Antarctic Marine Species (RAMS): a ten-year appraisal. ZooKeys 524: 137-145.

JUST J. and WILSON G.D.F. 2007. Revision of Austrosignum Hodgson and Munnogonium George \& Stromberg (Paramunnidae) with descriptions of eight new genera and two new species, (Crusatcea: Isopoda: Asellota). Zootaxa 1515: 1-29.

KAISER S., BARNES D.K.A. and BRANDT A. 2007. Slope and deep-sea abundance across scales: Southern Ocean isopods show how complex the deep sea can be. Deep-Sea Research II 54: $1776-1789$.

KAISER S. 2014. Antarctic and Sub-Antarctic isopod crustaceans (Peracarida, Malacostraca). In: C. De Broyer, P. Koubbi, H.J. Griffiths, B. Raymond and C. Udekem d'Acoz (eds), Biogeographic Atlas of the Southern Ocean. 5.18. Scientific Committee on Antarctic Research: 166-172.

Kędra M., Gromisz S., JaskuŁa R., Legeżyńska J., Maciejewska B., Malec E., OpanowSKi A., OstrowsKa K., WŁodARSKA-KowalcZUK M. and WęSŁAWSKi J.M. 2010. Soft bottom macrofauna of an All Taxa Biodiversity Site: Hornsund $\left(77^{\circ} \mathrm{N}\right.$, Svalbard). Polish Polar Research 31: 309-326.

LIPSKI M. 1987. Variations of physical conditions, nutrients and chlorophyll $a$ contents in Admiralty Bay (King George Island, South Shetland Islands, 1979). Polish Polar Research 8: 307-332.

MoOn H.W., Rauhan W.M., Hussin W., Kim H.C. and AHN I.Y. 2015. The impacts of climate change on Antarctic nearshore mega-epifaunal benthic assemblages in a glacial fjord on King George Island: Responses and implications. Ecological Indicators 57: 280-292.

NoRdenstam A. 1933. Marine Isopoda of the families Serolidae, Idotheidae, Pseudidotheidae, Arcturidae, Parasellidae and Stenetriidae main1y from the South Atlantic. Further Zoological Results of the Swedish Antarctic Expeditions 3: 1-284.

PABIS K. and SICIŃSKI J. 2010. Distribution and diversity of polychaetes collected by trawling in Admiralty Bay - an Antarctic glacial fiord. Polar Biology 33: 141-151.

PABIS K., SICIŃSKI J. and KRYMARYS M. 2011. Distribution patterns in the biomass of macrozoobenthic communities in Admiralty Bay (King George Island, South Shetlands, Antarctic). Polar Biology 34: 489-500.

PABIS K., BŁAŻEWICZ-PASZKowyCZ M., JÓŹWIAK P. and BARNES D.K.A. 2015. Tanaidacea of the Amundsen and Scotia Seas: an unexplored diversity. Antarctic Science 27: 19-30.

PĘCHERZEWSKI K. 1980. Distribution and quantity of suspended matter in Admiralty Bay (King George Island, South Shetland Islands. Polish Polar Research 1: 75-82.

PRESLER P. 1986. Necrophagous invertebrates of the Admiralty Bay of King George Island (South Shetland Islands, Antarctica). Polish Polar Research 7: 25-61.

RICHARDSON M.D. and HEDGPETH J.W. 1977. Antarctic soft-bottom, macro-benthic community adaptation to a cold, stable, highly productive, glacially affected environment. In: G.A. Llano 
(ed.), Adaptation within Antarctic ecosystems. Proceedings of the Third SCAR Symposium on Antarctic Biology. Smithsonian Institution, Washington DC: 181-196.

Sahade R., Lagger C., Torre L., Momo F., Monien P., Schloss I., Barnes D.K.A., Servetto N., TARAntelli S., Tatian M., Zamboni N. and Abele D. 2015. Climate change and glacier retreat drive shifts in an Antarctic benthic ecosystem. Science Advances 1: e1500050.

SCHOtTE M. 2008a. Coulmannia australis Hodgson, 1910. In: C.B. Boyko, N.L. Bruce, K.A. Hadfield, K.L. Merrin, Y. Ota, G.C.B. Poore, S. Taiti, M. Schotte and G.D.F. Wilson (eds), World Marine, Freshwater and Terrestrial Isopod Crustaceans database. Accessed through: C. De Broyer, A. Clarke, P. Koubbi, E. Pakhomov, F. Scott, E. Vanden Berghe and B. Danis (eds) 2017. Register of Antarctic Marine Species at http://www.marinespecies.org/rams/aphia. php?p=taxdetails\&id=175095 on 2017-06-26.

SCHOTTE M. 2008b. Munna psychrophila Vanhöffen, 1914. In: C.B. Boyko, N.L. Bruce, K.A. Hadfield, K.L. Merrin, Y. Ota, G.C.B. Poore, S. Taiti, M. Schotte and G.D.F. Wilson (eds), World Marine, Freshwater and Terrestrial Isopod Crustaceans database. Accessed through: C. De Broyer A., Clarke P., Koubbi E., Pakhomov F., Scott E., Berghe V. and Danis B. (eds) 2017. Register of Antarctic Marine Species at http://www.marinespecies.org/rams/aphia. php?p=taxdetails\&id=175105 on 2017-06-26.

SEROV P.A. and WILSON G.D.F. 1995. A Review of the Stenetriidae (Crustacea: Isopoda: Asellota). Records of the Australian Museum 47: 39-82.

SICIŃSKI J. 2004. Polychaetes of Antarctic sublittoral in the proglacial zone (King George Island, South Shetland Islands). Polish Polar Research 25: 67-96.

Siciński J., Jażdżewski K., De Broyer C., Presler P., Ligowski R., Nonato E.F., CorbiSiER T.N., PetTi M.A.V., Brito T.A.S., LaVrado H.P., BŁaŻeWicz-PASZKowyCZ M., PABIS K., JAŻDŻEWSKA A. and CAMPOS L.S. 2011. Admiralty Bay Benthos diversity - A census of a complex polar ecosystem. Deep-Sea Research II 58: 30-48.

SiCiŃSKi J., PABIS K., JAŻDŻEWSKI K., KonopaCKA A. and BŁAŻEWICZ-PASZKOWYCZ M. 2012. Macrozoobenthos of two Antarctic glacial coves: a comparison with non-disturbed bottom areas. Polar Biology 35: 355-367.

TeOdorCZYK W. and WÄGele J.W. 1994. On Antarctic species of genus Munna Kröyer, 1839 (Crustacea, Isopoda, Asellota, Munnidae). Bulletin du Muséum National d'Histoire Naturelle 16: 111-201.

TOKARCZYK R. 1987. Classification of water masses in the Bransfield Strait and southern part of the Drake Passage using a method of statistical multidimensional analysis. Polish Polar Research 8: 333-366.

WALSH J.E. 2009. A comparison of Arctic and Antarctic climate change, present and future. Antarctic Science 21: 179-188.

WILSON G.D.F. and SCHOTTE M. 2009. Coperonus gracilis. In: C.B. Boyko, N.L. Bruce, K.A. Hadfield, K.L. Merrin, Y.Ota, G.C.B.Poore, S. Taiti, M. Schotte and G.D.F. Wilson (eds) 2017. World Marine, Freshwater and Terrestrial Isopod Crustaceans database. Accessed through: World Register of Marine Species at http://www.marinespecies.org/aphia.php?p=taxdetails\&id=258104 on 2017-06-26.

WILSON G.D.F. 1989. A systematic revision of the deep-sea subfamily Lipomerinae of the isopod crustacean family Munnopsidae. Bulletin of the Scripps Institution of Oceanography University California, San Diego 27: 1-138.

Yoon C.K. 1993. Counting creatures great and small. Science 260: 620-622.

ZEMKO K. and BRIX S. 2011. New species of desmosomatid isopods from Admiralty Bay, King George Island. Polish Polar Research 32: 321-340. 
ZEMKO K. and KAISER S. 2012. Thambema thunderstruckae sp. n., the first record of Thambematidae (Isopoda: Asellota) from the Southern Hemisphere shelf. Polish Polar Research 33: $163-179$.

ZEMKo K., PABIS K., SicińSKi J. and BŁAŻEWICZ-PASZKOWYCZ M. 2015. Diversity and abundance of isopod fauna associated with holdfasts of the brown alga Himantothallus grandifolius in Admiralty Bay, Antarctic. Polish Polar Research 36: 405-415.

ZEMKO K., PABIS K., SiCIŃSKI J. and BŁAŻEWICZ M. 2017. Low abundance and high species richness: the structure of the soft-bottom isopod fauna of a West Antarctic glacial fjord. Polar Biology DOI: 10.1007/s00300-017-2133-0

ZIELIŃSKI K. 1990. Bottom macroalgae of the Admiralty Bay (King George Island, South Shetlands, Antarctica). Polish Polar Research 11: 95-131.

Received 29 March 2017

Accepted 15 June 2017 